\title{
Nocturnal hypoxia and prolactin secretion in obese women
}

\author{
P G KOPELMAN, M C P APPS, T COPE, D W EMPEY
}

\begin{abstract}
Respiration during sleep was studied in six obese women who had impaired prolactin response to insulin induced hypoglycaemia (non-responders), six obese women with a normal prolactin response to hypoglycaemia (responders), and six lean women. Sleep apnoea did not occur in any subject. All the obese women showed a decrease in haemoglobin oxygen saturation when asleep, which occurred predominantly during periods of rapid eye movement sleep.

That the fall in oxygen saturation was significantly greater $(p<0.05)$ in the obese non-responders suggests that central as well as mechanical factors may be important for the genesis of nocturnal hypoxia and is evidence for a disturbance of central nervous function in some obese women.
\end{abstract}

\section{Introduction}

Obese men reportedly show episodes of hypoxia with oxygen desaturation and apnoea during sleep, ${ }^{1}$ which is quite distinct from the rare complication of obesity of daytime hypoventilation and hypersomnolence (Pickwickian syndrome). ${ }^{2}$ In contrast, disordered breathing during sleep has not been observed in obese premenopausal women, and hormonal differences have been suggested as an explanation. ${ }^{3}$ We have reported evidence for a disorder of hypothalamic function in some obese women. ${ }^{4-5}$ These women have no prolactin response to insulin induced hypoglycaemia and are termed prolactin "non-responders," whereas other equally obese women show a normal prolactin response to hypoglycaemia ("responders").

This study investigates whether abnormalities of respiration

The London Hospital, Whitechapel, London E1 1BB

P G KOPELMAN, MD, MRCP, lecturer in metabolism and endocrinology

M C P APPS, MA, MRCP, senior registrar in respiratory medicine

$T$ COPE, SRN, research nurse, department of respiratory medicine

D W EMPEY, $\mathrm{MB}$, FRCP, consultant in respiratory medicine

Correspondence to: Dr P G Kopelman. during sleep occur in obese premenopausal women and whether there are any differences between those women who have a normal prolactin response to insulin hypoglycaemia and those with no response.

\section{Subjects and methods}

Table I gives the details of the subjects studied. The obese patients were volunteers who were attending the obesity clinic; all subjects had normal thyroid function and reportedly normal menstrual cycles. The intravenous insulin tolerance test was carried out as described ${ }^{4}$ : 0.15 unit Actrapid insulin $/ \mathrm{kg}$ body weight was given to the obese subjects and $0 \cdot 1$ unit $/ \mathrm{kg}$ body weight to the normal (lean) subjects. After insulin the blood glucose concentration fell to less than $40 \%$ of the fasting value, and this fall was accompanied by symptoms in all subjects. Prolactin was measured by specific radioimmunoassay; the standard used was IRP75/504. The insulin tolerance test was performed at least four weeks before or after the sleep study. Pulmonary function was assessed using a Wright peak flow meter and a Vitalograph dry spirometer.

Respiration during sleep was observed overnight in a quiet, darkened room: obese subjects were studied for two nights and the lean subjects for one. Air flow at the nose and mouth was sensed with thermistors mounted on nasal cannulae and with a laryngeal microphone. Movement of the chest and abdomen was assessed with inductance bands (Respitrace). Apnoea was defined as a pause in air flow for more than 10 seconds. Percentage haemoglobin oxygen saturation was measured with a Hewlett Packard ear lobe oximeter. Sleep was staged with an electroencephalogram $\left(\mathrm{C}_{4} \mathrm{~A}_{1}\right)$, electrooculogram, and submental electromyogram using standard methods. One of the investigators remained at the bedside throughout, noting the subject's behaviour, such as snoring or restlessness, and recording this on the tracing. Timing of events was also recorded on the tracing and each tracing reviewed in detail and correlated with the stage of sleep.

Statistical analysis was by a Wilcoxon non-parametric test, because the results suggested that the groups were not normally distributed.

Each subject gave fully informed, written consent and the study was approved by the hospital's ethical committee.

\section{Results}

Insulin tolerance test-Table I shows the prolactin responses to hypoglycaemia in the 12 obese subjects and three of the six lean controls in whom the test was carried out. Six of the obese subjects 
were found to be "non-responders" and six "responders." Responses in the three lean subjects were similar to those seen in our previous studies. $^{5}$

Pulmonary function tests (table I)-All the patients and controls had normal spirometric values - that is, between $75^{\circ} \mathrm{ond} 125 \%$ of predicted normal. Two non-responders and one responder smoked 10-20 cigarettes daily; all the controls were non-smokers.
Sleep study (table II ; figure)-No subject showed any apnoeic episodes. Mean values for oxygen saturation were calculated from the average saturation on each page of the record during the study. The lean controls showed little change in oxygen saturation when asleep, but in the obese subjects there was a fall; the difference was significant (p. 0.01). Mean oxygen saturations awake and asleep were similar in the two groups of obese subjects. Minimum oxygen saturation

TABLE I-Details of women studied, results of respiratory function tests, and prolactin concentrations (basal and during insulin tolerance test)

\begin{tabular}{|c|c|c|c|c|c|c|c|c|}
\hline \multirow[b]{2}{*}{ Subject No } & \multirow{2}{*}{$\underset{\text { (years) }}{\text { Age }}$} & \multirow{2}{*}{$\begin{array}{c}\text { Weight } \\
(\mathrm{kg})\end{array}$} & \multirow{2}{*}{$\begin{array}{l}\text { Body mass index } \\
\text { (weight } / \text { height }^{2} \text { ) }\end{array}$} & \multirow[b]{2}{*}{$\mathrm{VC}^{*}$} & \multirow[b]{2}{*}{$\mathrm{FEV}_{1} *$} & \multirow[b]{2}{*}{ PEFR* } & \multicolumn{2}{|c|}{ Prolactin } \\
\hline & & & & & & & $\begin{array}{c}\text { Basal value } \\
(\mathrm{mU} / 1)\end{array}$ & TIR† \\
\hline \multicolumn{9}{|c|}{ Obese non-responders } \\
\hline $\begin{array}{l}1 \\
2 \\
3 \\
4 \\
5 \\
6\end{array}$ & $\begin{array}{l}30 \\
21 \\
23 \\
24 \\
18 \\
16\end{array}$ & $\begin{array}{r}80 \\
103 \\
125 \\
110 \\
106 \\
75\end{array}$ & $\begin{array}{l}30 \\
43 \\
45 \\
40 \\
36 \\
27\end{array}$ & $\begin{array}{r}109 \\
98 \\
85 \\
109 \\
94 \\
111\end{array}$ & $\begin{array}{r}110 \\
102 \\
95 \\
104 \\
96 \\
125\end{array}$ & $\begin{array}{r}101 \\
90 \\
97 \\
95 \\
101 \\
120\end{array}$ & $\begin{array}{l}400 \\
152 \\
158 \\
397 \\
155 \\
448\end{array}$ & $\begin{array}{r}-569 \\
-150 \\
-299 \\
-690 \\
36 \\
37\end{array}$ \\
\hline $\begin{array}{l}\text { Mean } \\
(\text { SEM })\end{array}$ & $22(2)$ & $100(8)$ & $37(3)$ & & & & $285(58)$ & -272 \\
\hline
\end{tabular}

\begin{tabular}{|c|c|c|c|c|c|c|c|c|}
\hline \multicolumn{9}{|c|}{ Obese responders } \\
\hline 7 & 24 & 95 & 36 & 105 & 100 & 116 & 138 & 5482 \\
\hline 8 & 28 & 103 & 35 & 100 & 104 & 95 & 134 & 2921 \\
\hline 9 & 42 & 85 & 30 & 78 & 84 & 101 & 150 & 5490 \\
\hline 10 & 22 & 105 & 42 & 94 & 95 & 98 & 502 & 7406 \\
\hline 11 & 38 & 95 & 34 & 85 & 90 & 100 & 72 & 1552 \\
\hline 12 & 23 & 125 & 41 & 75 & 86 & 102 & 392 & 2771 \\
\hline $\begin{array}{c}\text { Mean } \\
(\text { SEM) }\end{array}$ & $29(4)$ & $101(6)$ & 36 & & & & $231(70)$ & 4270 \\
\hline
\end{tabular}

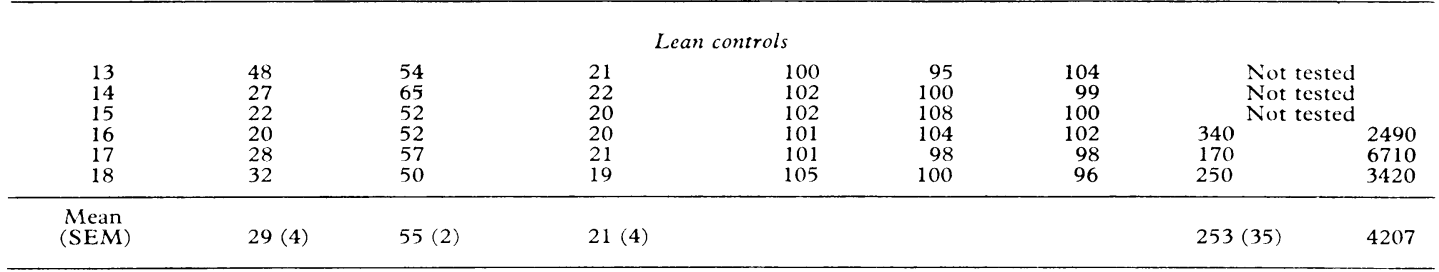

*Vital capacity (VC), forced expiratory volume in one second $\left(\mathrm{FEV}_{1}\right)$, and peak expiratory flow rate (PEFR) expressed as percentages of predicted normal.

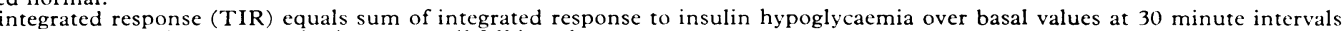
up to two hours. Negative response indicates overall fall in values.

TABLE II-Nocturnal oxygen saturation in obese women and lean controls

\begin{tabular}{|c|c|c|c|c|c|c|}
\hline \multirow[b]{2}{*}{$\begin{array}{l}\text { Subject } \\
\text { No }\end{array}$} & \multicolumn{4}{|c|}{ Haemoglobin oxygen saturation $\left({ }^{\circ}\right.$ ) } & \multicolumn{2}{|c|}{ Sleep analysis } \\
\hline & $\begin{array}{l}\text { Mean } \\
\text { awake }\end{array}$ & $\begin{array}{l}\text { Mean } \\
\text { asleep }\end{array}$ & $\begin{array}{l}\text { Minimum } \\
\text { asleep }\end{array}$ & $\begin{array}{l}\text { Time } \\
\text { (min) } \\
\text { (min) }\end{array}$ & $\begin{array}{l}\text { Total } \\
\text { sleep } \\
\text { time } \\
\text { (min) }\end{array}$ & $\begin{array}{l}\text { Time in } \\
\text { REM } \\
\text { sleep } \\
(\mathrm{min})\end{array}$ \\
\hline \multicolumn{7}{|c|}{ Obese non-responders } \\
\hline $\begin{array}{l}1 \\
2 \\
3 \\
4 \\
5 \\
6\end{array}$ & $\begin{array}{l}97 \\
96 \\
97 \\
97 \\
98 \\
97\end{array}$ & $\begin{array}{l}94 \\
93 \\
94 \\
94 \\
95 \\
95\end{array}$ & $\begin{array}{l}85 \\
84 \\
89 \\
87 \\
90 \\
93\end{array}$ & $\begin{array}{r}6.0 \\
168.0 \\
2.5 \\
3.0 \\
1.5 \\
\text { Nil }\end{array}$ & $\begin{array}{r}243 \\
333 \\
95 \\
280 \\
408 \\
338\end{array}$ & $\begin{array}{l}38 \\
75 \\
10 \\
53 \\
74 \\
58\end{array}$ \\
\hline $\begin{array}{l}\text { Mean } \\
\text { (SEM) }\end{array}$ & $97(0 \cdot 2)$ & $94(0.3)$ & $88(1 \cdot 4)$ & & $282(45)$ & $51(10)$ \\
\hline \multicolumn{7}{|c|}{ Obese responders } \\
\hline $\begin{array}{r}7 \\
8 \\
9 \\
10 \\
11 \\
12\end{array}$ & $\begin{array}{l}98 \\
98 \\
99 \\
97 \\
98 \\
98\end{array}$ & $\begin{array}{l}95 \\
95 \\
96 \\
95 \\
95 \\
96\end{array}$ & $\begin{array}{l}94 \\
92 \\
92 \\
93 \\
94 \\
94\end{array}$ & $\begin{array}{l}\text { Nil } \\
\text { Nil } \\
\text { Nil } \\
\text { Nil } \\
\text { Nil } \\
\text { Nil }\end{array}$ & $\begin{array}{l}336 \\
433 \\
190 \\
320 \\
238 \\
291\end{array}$ & $\begin{array}{l}65 \\
66 \\
17 \\
28 \\
38 \\
44\end{array}$ \\
\hline $\begin{array}{l}\text { Mean } \\
(\mathrm{SEM})\end{array}$ & $98(0 \cdot 3)$ & $95(0 \cdot 2)$ & $93(0 \cdot 4)$ & & $301(35)$ & $43(8)$ \\
\hline \multicolumn{7}{|c|}{ Lean controls } \\
\hline $\begin{array}{l}13 \\
14 \\
15 \\
16 \\
17 \\
18\end{array}$ & $\begin{array}{l}98 \\
98 \\
99 \\
99 \\
99 \\
98\end{array}$ & $\begin{array}{l}98 \\
98 \\
98 \\
98 \\
98 \\
97\end{array}$ & $\begin{array}{l}97 \\
97 \\
96 \\
98 \\
98 \\
95\end{array}$ & $\begin{array}{l}\text { Nil } \\
\text { Nil } \\
\text { Nil } \\
\text { Nil } \\
\text { Nil } \\
\text { Nil }\end{array}$ & $\begin{array}{l}243 \\
253 \\
263 \\
310 \\
237 \\
157\end{array}$ & $\begin{array}{l}28 \\
32 \\
45 \\
50 \\
50 \\
37\end{array}$ \\
\hline $\begin{array}{c}\text { Mean } \\
\text { (SEM) }\end{array}$ & $98(0.2)$ & $98(0 \cdot 2)$ & $97(0.5)$ & & $244(21)$ & $44(4)$ \\
\hline
\end{tabular}

REM = Rapid eye movement

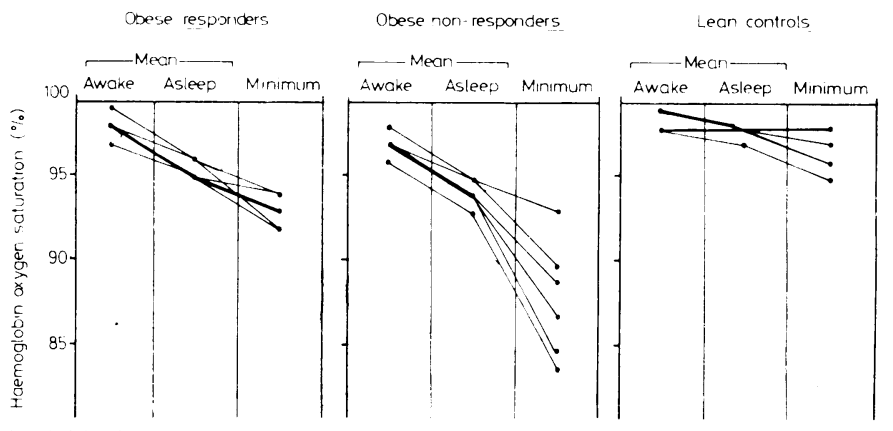

Individual nocturnal oxygen saturations in subjects studied.

which was observed in all subjects during rapid eye movement sleep, was significantly lower in the obese non-responders than in the responders ( $p-0.05)$, and in five of the six non-responders some time was spent with an oxygen saturation below $90 \%$. None of the responders showed a fall in oxygen saturation below $92^{\circ}{ }_{\ldots}$. Total sleep and rapid eye movement sleep time (table II) were not significantly different among the three groups, although the controls (studied for only one night) slept for shorter time than the obese subjects.

\section{Discussion}

These studies show that obese premenopausal women have periods of oxygen desaturation but do not have apnoeic episodes during sleep. Probably an excessive amount of abdominal adipose tissue partly accounts for this, because vital capacity, 
expiratory reserve volume, and chest wall compliance are often reduced by obesity, and a change from sitting to the supine position may further reduce them. ${ }^{6} 7$ Nevertheless, the fall in oxygen saturation-which occurs predominantly during rapid eye movement sleep-is significantly greater in those women with abnormal prolactin secretion (non-responders). This group of women cannot be distinguished from responders by weight; body mass index, age, or physical characteristics. We and others ${ }^{8}{ }^{9}$ have suggested that the alterations of prolactin secretion in obesity may result from a disorder of hypothalamic function rather than as an effect of prolactin itself on fat metabolism. Our present findings are further evidence for a disturbance of central nervous function in such women.

Prolactin secretion fluctuates during sleep: the highest plasma concentrations are seen during non-rapid eye movement sleep, whereas the lowest concentrations are associated with rapid eye movement sleep. ${ }^{10}$ Respiratory drive is also altered by the stage of sleep and may be reduced during rapid eye movement sleep with a concomitant small decrease in oxygen saturation. ${ }^{11}$ There is evidence that prolactin secretion is predominantly under the inhibitory control of hypothalamic dopaminergic mechanisms, ${ }^{12}$ but there are also stimulatory serotoninergic mechanisms. ${ }^{13}$ Furthermore, dopaminergic pathways appear to be important for rapid eye movement sleep and serotoninergic pathways for non-rapid eye movement sleep. ${ }^{14}$ We may only speculate that these two central nervous mediators are also implicated in the control of respiration.

We conclude that a decrease in oxygen saturation (but not apnoeic episodes) occurs in premenopausal obese women during sleep. Those women with abnormal prolactin secretion show a significantly greater fall in oxygen saturation. This is evidence for central as well as mechanical factors in the genesis of the nocturnal hypoxia and supports the hypothesis for a central disturbance in obesity.

We thank Dr D Scott and Dr P Sheaff, of the department of clinical neurophysiology, for their help with the study; Dr N White and colleagues (department of endocrinology at the Chelsea Hospital for
Women) for prolactin measurements; and Miss $P$ Nibbs for secretarial work. TC is supported by a grant from Tower Hamlets Health District Research Advisory Committee.

\section{References}

${ }^{1}$ Block AJ, Boysen PG, Wynne JW, Hunt LA. Sleep apnea, hypoapnea and oxygen desaturation in normal subjects. $N$ Engl $\mathcal{F}$ Med 1979;300: 513-7.

${ }^{2}$ Harman E, Wynne JW, Block AJ, Malloy Fisher L. Sleep disordered breathing and oxygen desaturation in obese patients. Chest $1981 ; 79$ : 256-60.

${ }^{3}$ Burwell CS, Robin ED, Whaley RD, Bickelman AG. Extreme obesity associated with alveolar hypoventilation-Pickwickian syndrome. $\mathrm{Am}$ T Med 1956;21:81-8.

4 Kopelman PG, Pilkington TRE, White N, Jeffcoate SL. Impaired hypothalamic control of prolactin secretion in massive obesity. Lancet $1979 ; \mathrm{i}: 747-9$.

${ }^{5}$ Kopelman PG, Pilkington TRE, White N, Jeffcoate SL. Evidence for the existence of two types of massive obesity. Br Med $71980 ; 280: 82-3$.

- Farebrother MJB. Respiratory function and cardiorespiratory response to exercise in obesity. Br $\mathcal{F}$ Dis Chest 1979;73:211-29.

7 Sharp JT, Henry JP, Sweany SK, et al. Effects of mass loading the respiratory system in man. $\mathcal{f}$ Appl Physiol 1964;19:959-66.

${ }^{8}$ Kopelman PG, Pilkington TRE, White N, Jeffcoate SL. Persistence of defective hypothalamic control of prolactin secretion in some obese women after weight reduction. $\mathrm{Br} M e d$ F 1980;281:358-9.

9 Jung RT, Campbell RG, James WPT, Callingham B. Altered hypothalamic sympathetic responses to hypoglycaemia in familial obesity. Lancet $1982 ; \mathrm{i}: 1043-6$

${ }^{10}$ Parker DC, Rossman LG, Vanderlaan EF. Relation of sleep entrained human prolactin release to REM-non REM cycles. $\mathcal{f}$ Clin Endocrinol Metab 1974;38:646-51.

11 White DP, Douglas NJ, Pickett CK, et al. Hypoxic ventilatory response during sleep in normal pre-menopausal women. Am Rev Respir Dis $1982 ; 126: 530-3$.

12 MacCleod RM, Lehmeyer JE. Studies on the mechanism of the dopaminemediated inhibition of prolactin secretion. Endocrinology 1974;94 1077-85.

13 MacIndoe JH, Turkington $\mathrm{RW}$. Stimulation of human prolactin secretion by intravenous infusion of L-tryptophan. $\mathcal{F}$ Clin Invest 1973;52:1972-8.

${ }^{14}$ Stock G. In: Ganten D, Pfaff D, eds. Neurobiology of sleep. Berlin: Springer-Verlag, 1982:1-36.

(Accepted 28 fune 1983)

\title{
Disseminated candidiasis: evidence of a distinctive syndrome in heroin abusers
}

\author{
PETER J COLLIGNON, TANIA C SORRELL
}

\begin{abstract}
Seven young men developed similar manifestations of disseminated candidiasis after a single episode of intravenous heroin abuse. Sequential development of lesions of the eye, skin, and bone or costal cartilage was noted within 10 days after injection. Skin lesions were confined to the scalp and other hair bearing areas. Candida albicans was cultured readily from affected skin and

\footnotetext{
Infectious Disease Medicine, Westmead Hospital, Westmead, New South Wales 2145, Australia

PETER J COLLIGNON, MB, BS, senior registrar

TANIA C SORRELL, MD, FRACP, head (also senior lecturer in medicine, University of Sydney)

Correspondence to: Dr T C Sorrell, Department of Medicine, Westmead Hospital, Westmead, NSW 2145, Australia.
}

costal cartilage. Histological examination of scalp biopsy specimens showed infiltration of hair follicles with chronic inflammatory cells and $C$ albicans. Pseudohyphas of $\mathrm{C}$ albicans were also identified in and around hair shafts. The skin, skeletal, and small eye lesions resolved on systemic treatment with $1 \mathrm{~g}$ amphotericin $B$ plus flucytosine. Pars plana vitrectomy plus local instillation of amphotericin $B$ cured progressive chorioretinitis.

These features may represent a distinctive syndrome of disseminated candidiasis in heroin abusers. Systemic antifungal treatment is curative in most cases.

\section{Introduction}

After intravenous heroin abuse seven young men presented with disseminated candidiasis affecting several organs. Characteristic skin and eye lesions, and frequent inflammation of 